\section{Lessons From a Severe Outbreak of Meningitis and Gastroenteritis Among Staff of a British Field Hospital in Afghanistan}

Col.Timothy John Hodgetts, $M M E d, M B, B S, F R C P$, FRCSEd, FFAEM, FIMCRCSEd, FRGS, L/RAMC Defence Consultant Adviser and Professor, Emergency Medicine and Trauma, Royal Centre for Defence Medicine, Birmingham, UK

The Norwalk-like virus is a common cause of gastroenteritis with a high attack rate that has been recognized to affect closed military or health service populations. This paper describes an atypical and severe presentation within the staff of a small British Army field hospital in Afghanistan in 2002. A total of $41 \%$ (31/76) of the hospital's staff were admitted between 12 and 17 May 2002, with a further $20 \%$ (15/76) placed in quarantine. An additional 15 cases from surrounding military units were admitted during the same period. Five cases had symptoms of meningitis, and two of these required mechanical ventilation (one case developed disseminated intravascular coagulopathy). Diagnosis was confirmed by electron microscopy of stool, polymerase chain reaction, and ELISA on patients evacuated to the UK. Lessons relating to infectious control measures in the field, limited field diagnostic support for infectious disease outbreaks, and the impact on sustaining the provision of medical care for deployed troops are presented.

Keywords: diagnosis; disseminated intravascular coagulopathy

(DIC); epidemic; field hospital; gastroenteritis; meningitis; military; Norwalk-like virus

Prehosp Disast Med 2003:18:s(1)s6.

E-mail: timothy.hodgetts@uhb.nhs.uk

\section{When the Heroes Have Left - Identification in Mass Casualty Situations \\ Surgeon Commander RDNR Peter J.T. Knudsen \\ President, CIOMR (Interallied Confederation of Medical Reserve Officers)}

In mass casualty situations, the first and foremost efforts of the authorities are the saving of human lives and the prevention of escalation of the situation that could result in casualties. But when the rescue work is over, the follow-up work begins. The two main preoccupations will be the identification of the fatally injured and finding the cause of the situation, if it is not obvious, as in earthquakes and floods. The identification work generally is led by the police, but forensic pathologists have a key role. However, they are not alone, because they work with the police and fellow experts such as forensic dentists, geneticists, and anthropologists. The main stumbling block for this kind of work is not in the details of anatomy or pathology, but the logistics and cooperation with the local authorities and those in charge of locating information about the deceased ante- mortem. Though a military medical background is not a necessity, it can be very useful when dealing with such situations. As an officer, you are used to working with hierarchal organizations in which rank counts, and as a medical officer, you know the intricacies of the medical world that you are dependent upon for a successful identification. You also may have to rely on military experts in areas such as aviation pathology, and here again your military background will again make life easier.

Keywords: civilian; cooperation; identification of remains; military, rank; pathology, forensic

Prehosp Disast Med 2003:18:s(1)s6.

E-mail: pthiis@health.sdu.dk

\section{Lessons Learned from Deployments to Disaster Areas Worldwide \\ LTC (Ret.) Mauricio Lynn, MD \\ Rider Trauma Center, Jackson Memorial Hospital, University of Miami School of Medicine, Miami, Florida, USA}

Deployment of medical teams into disaster areas is associated with significant planning challenges that cannot be standardized, but rather must be tailored for each specific task. Knowledge of the primary mission of the team to be deployed is key in composing the personnel, structuring the equipment and supplies and coordinating the logistics. The presentation will summarize important lessons learned from five deployments of medical teams to areas of disasters such earthquakes, airline accident, humanitarian mission and terrorist induced mass casualty incident.

Keywords: deployment; disaster; lessons; logistics; medical teams; personnel; planning; standardization

Prehosp Disast Med 2003:18:s(1)s6.

\section{Our Experience as Role 1 Staff in SFOR (NATO) Operations Joint Force in Sarajevo-BIH 2000-2002 Andrej Strabovnik, MD; Slavisa Mihaljeviè, $M D$; Bozidar Pekaroviè, MD; Niko Strliè, $M D$ \\ Splosna Bolnisnica Celje; General Hospital, Celje, Slovenia}

Since February 2000, a Slovenian Armed Forces medical unit has been providing medical assistance to SFOR members in Sarajevo. Among our activities at the ROLE 1 level are providing medical services, including emergency, minor surgery, preventive medicine, pharmacy, medical education, and training of the SFOR staff. Our prerequisites include: knowing the cultural background of the area, knowledge of the local language, continuous presence of a surgeon, permanent pharmaceutical supply, and fast adaptability.

A total of 6,000 patients were examined in 2001; 135 minor surgeries were done; $453(8 \%)$ were sent to ROLE 3 ; and 48 were emergencies. Good cooperation between civilian and military medical authorities contributed to the quality of the medical services provided, which when combined, exceeded the ROLE 1 activity level.

Conclusions: All civilian doctors who served as a ROLE 1 staff should keep in contact with military medical authorities after their service.

Keywords: adaptability; army, Slovenian Armed Forces; civil-military; cooperation; customs; language; pharmaceuticals; prerequisites; preventive medicine; Sarajevo; SFOR; surgery

Prebosp Disast Med 2003:18:s(1)s6.

E-mail: andrej.strahovnik1@guest.arnes.si 